\section{A long view of history}

SIR - E. Guthy (Nature 348, 670; 1990) is correct in pointing out that a long view of history absolves the Germans of greater aggressiveness than other European powers. What is striking in German history, however, at least before the Second World War, is the failure to form stable political systems capable of dealing with severe internal and external stress. Even Bismarck, masterful politician that he was, was not able to manage the system he had created without alternately targeting socialists, Catholics or (to a lesser extent) Jews for transient advantage. Moreover, the peculiar idea, springing from German romanticism but made explicit by Hegel, that the state itself possessed an organic life and natural rights apart from those of its citizens, was to have a long-lasting and terrible influence.

Guthy is somewhat disingenuous in his portrayal of Germany's beneficent influence on Central Europe in the years before the First World War. Certainly Austria would not have gone to war against Serbia in 1914 without encouragement from Germany. This, coming as it did from the Kaiser and general staff, bypassing the chancellor, illustrates the political failure. It is German historians who have taught us that war in 1914 was seen by many in Germany as necessary to resolve otherwise insoluble problems: "encirclement" by the Russians and the French; the implications of a socialist majority in the Reichstag; decline of the East Elbian aristocracy. And indeed German war aims, not just as advocated by more or less influential groups such as the Pan-German League, but articulated in the Brest-Litovsk Treaty, were not those of a power seeking only to preserve the status quo or redress recent losses.

German political evolution had been frozen at what was for Western Europe an intermediate stage on the road towards true representative government: the combination of an authoritarian executive with an elected parliament. As a result, there was no tradition of political accountability. During the war, Allied politicians knew the price of failure was loss of office; for the German government, it was revolution.

The instability of Imperial Germany, and its political failure, was of course exacerbated by the First World War. In the Weimar era, neither will nor resources were sufficient to suppress violent political deviance or to devise legitimate means of expression for the concerns that bred such violence. Although Hitler's regime was radically different from the Kaiser's, it was not totally discontinuous. In the former case an ideological, in the latter a military, dictatorship had been allowed to control the country. In fact one of the most interesting differences, and an indication that things do change, is the relative lack of influence of the military under the Nazis. Thus, the rejoinder to the fear of W. Frank Harris (Nature 347, 510; 1990) that Germany in 2000 will act no differently than in 1900 or 1930 must be that different political structures are now in place. Moreover, the ultranationalist ideology popular among at least a significant minority of Germans in 1900 as well as 1930 seems much less prevalent now.

It is important to face problems openiy. In the United States, the legacy of 300 years of slavery has not been erased entirely in the 100 since abolition. By now, certainly, Germany is experienced enough in democracy, and rich enough, to deal with the problems presented by unification, as long as everyone keeps the past, not in a closet, but in a quiet corner in the back of the mind.

6328 Lenox Road,

Bethesda, Maryland 20817, USA

\section{Order, order!}

SIR - John Maddox's News and Views article "Should camp-followers be policemen?" (Nature 348, 107; 1990) raises again the issue of research article authorship. While it is widely acknowledged that the practice of a senior researcher adding his or her name to a paper in honorary co-authorship is morally dubious, there is at least one pragmatic argument in favour of such a system - it can greatly facilitate literature searches. Searching against a (well known) senior author's name in reference listing (for example, Index Medicus, and especially the now widely available CD-ROM citation indexing) is likely to achieve a fruitful 'trawl' of relevant papers, highly desirable in these times of burgeoning publications.

University of Oxford,

R.D. EVANS

Nuffield Department of Anaesthetics.

Radcliffe Infirmary,

OXford OX2 6HE. UK

SIR-Apportioning credit to each author of a multi-authored work continues to be a matter of guesswork. How is a reader to know, to mention examples with which I am familiar, that an author was listed only because he was department chair, or because he was a friend of the editor of a leading journal? What is one to make of a note added in proof advising readers to invert the published order of the authors in future references to the paper? Perhaps we need to devise a system to let employers, granting agencies, historians and (let's face it) gossips know what each author thought the others contributed.
Accordingly, I propose that we assign meaning to the punctuation marks used to separate authors' names. Thus, if authors believed that each contributed equally, a comma would continue to be used after each name. In more difficult cases, alternative punctuation would be used. For example, those authors who contributed equally to a multi-authored work might be listed together without commas, followed by a semicolon and the lesser authors. More imaginatively, the name of the department chair might be followed with a subscript star, the friend of the editor with a small double-headed arrow, and an author who contributed only money with a $\$$, $£$ or $¥$. Question and exclamation marks could be used in particularly interesting ways.

This system should appeal to scientists; it is arcane, expandable, infinitely arguable, wholly uninterpretable to readers not in the system and usable by bibiolographic services. The only major problem I can see is that a large percentage of authors would seem to gain nothing by such disclosure.

Neuroscience Center, Massachusetts General Hospital, Boston, Massachusetts 02129, USA

\section{Not so old}

SIR-Perhaps a reasonably correct historical sense is not absolutely necessary in news items, but Britain's Astronomer Royal' (Nature 349, 93; 1991) is a title that dates back only to 1972 when Sir Richard Woolley ceased to be 'Astronomer Royal of England". It is the latter title that dates back to the seventeenth century and it was never 'an honorary position' but was coterminous with the directorship of the Royal Observatory at Greenwich until 1950 and then of the Royal Greenwich Observatory at Herstmonceux. At present there is no Astronomer Royal of Scotland so that the use of the term 'Britain' in Professor Wolfendale's appointment may be unwelcome to some Scottish readers. It may be further mentioned that, although the Andrews' Professor of Astronomy in the University of Dublin was conferred by George III (Letters Patent, 32 Geoll, 1792) with the title "for ever" of Royal Astronomer of Ireland, it was tacitly understood that this provision lapsed in 1966 when the statutes of the university were revised.

PATRICKA. WAYMAN Andrews' Professor of Astronomy (Honorary)

Dunsink Observatory,

Dublin 15, Ireland

Letters submitted for Correspondence should be typed, double-spaced, on one side of the paper only. 